\title{
VALIDATION OF THE PORTUGUESE VERSION OF THE TAMPA SCALE FOR KINESIOPHOBIA HEART (TSK-SV HEART)
}

\author{
VALIDAÇÃO DA VERSÃO EM PORTUGUÊS DA ESCALA DETAMPA PARA CINESIOFOBIA CARDÍACA \\ (TSK-SV CARDÍACA)
}
VALIDACIÓN DE LA VERSIÓN EN PORTUGUÉS DE LA ESCALA DE TAMPA PARA KINESIOFOBIA CARDIACA (TSK-SV CARDIACA)

\begin{abstract}
Gabriela Lima de Melo Ghisi' (Physiotherapist)

Rafaella Zulianello dos Santos ${ }^{2}$ (Physical Education Professional)

Thiago Renee Felipe 3,6

(Physical Education Professional)

Christiani Decker Batista Bonin²

(Physiotherapist)

Edson Fonseca Pinto 3,4

(Physical Education Professional)

Felipe Eduardo Fernandes Guerra ${ }^{5}$ (Doctor)

Maria Irany Knackfuss ${ }^{3}$

(Physical Education Professional)

Paul Oh'

(Doctor)

Magnus Benetti ${ }^{2}$

(Physical Education Professional)
\end{abstract}

1. University Health Network, Toronto Rehabilitation Institute, Cardiovascular Prevention and Rehabilitation Program, Toronto, Ontario, Canada.

2. Universidade do Estado de Santa Catarina, Centro de Ciências e Desportos em Saúde, Florianopolis, Santa Catarina, Brazil.

3. Universidade Estadual do Rio Grande do Norte, Rio Grande do Norte, Natal, Brazil.

4. Universidade Federal do Rio Grande do Norte, Programa de Biotecnologia do Nordeste, Natal, RN, Brazil.

5. Clínica do Exercício, Serviço de Reabilitação Cardiáca, Natal, RN, Brazil.

6. Universidade Potiguar - UnP, Rio Grande do Norte, Natal, Brazil.

\section{Correspondence:}

Rafaella Zulianello dos Santos Universidade do Estado de Santa Catarina, Centro de Ciências e Desportos em Saúde, 358, Coqueiros, Florianopolis, SC, Brazil. 88080350.

rafaella.zulianello@gmail.com

\begin{abstract}
Introduction: It has been shown that kinesiophobia has a negative influence on the outcomes of cardiac rehabilitation and consequently is important for the clinical setting. Objective: The objective of this study was to translate, culturally adapt, and psychometrically validate the Tampa Scale for Kinesiophobia Heart (TSK-SV Heart) to Brazilian Portuguese. Methods: The Portuguese version was tested in 300 patients in cardiac rehabilitation. Test-retest reliability was assessed by intraclass correlation coefficient, internal consistency by Cronbach's alpha, and criterion validity was assessed with respect to patients' education, income, duration of cardiac rehabilitation, and sex. Results: After intraclass correlation coefficient analysis, one item was excluded. All four areas were considered internally consistent ( $a>0.7)$. Significant differences between mean total scores and income $(p<0.01)$ supported the criterion validity. Two hundred sixty-nine $(89.6 \%)$ patients had a high level of kinesiophobia (scores > 37). Conclusions: The Brazilian Portuguese version of TSK-SV Heart demonstrated sufficient reliability, consistency and validity, supporting its use in future studies.
\end{abstract}

Keywords: coronary artery disease; rehabilitation; surveys and questionnaires; fear; movement; validation studies.

\section{RESUMO}

Introdução: Demonstrou-se que a cinesiofobia tem influência negativa sobre os resultados da reabilitação cardíaca e, consequentemente, é importante no contexto clínico. Objetivo: O objetivo deste estudo foi traduzir, fazer a adaptação cultural evalidar em termos psicométricos a Escala de Tampa para Cinesiofobia Cardiaca (TSK-SV Cardíaca) para o português do Brasil. Métodos: A versão em português foi testada em 300 pacientes em reabilitação cardíaca. A confiabilidade teste-reteste foi avaliada pelo coeficiente de correlação intraclasse, a consistência interna pelo alfa de Cronbach, e a validade de critério foi avaliada no que diz respeito a educação dos pacientes, renda, duração da reabilitação cardíaca e sexo. Resultados: Após análise do coeficiente de correlação intraclasse, um item foi excluido. Todas as quatro áreas foram consideradas internamente consistentes $(a>0,7)$. As diferenças significativas entre os escores totais médios e de renda $(p<0,01)$ apoiaram a validade de critério. Duzentos e sessenta e nove $(89,6 \%)$ pacientes apresentavam um alto nivel de cinesiofobia (escore > 37). Conclusões: A versão em português do Brasil da TSK-SV Cardíaca demonstrou ter confiabilidade, consistência e validade suficientes, apoiando a sua utilização em estudos futuros.

Descritores: doença da artéria coronariana; reabilitação; inquéritos e questionários; medo; movimento; estudos de validação.

\section{RESUMEN}

Introducción: Se ha demostrado que la kinesiofobia tiene una influencia negativa sobre el resultado de la rehabilitación cardiaca y, por consiguiente, es importante en el contexto clínico. Objetivo: El objetivo de este estudio fue traducir, hacer la adaptación cultural y la validación en términos psicométricos de la Escala de Tampa para Kinesiofobia Cardiaca (TSK-SV Cardiaca) al portugués de Brasil. Métodos: La versión portuguesa se probó en 300 pacientes en rehabilitación cardiaca. Se evaluó la fiabilidad test-retest por el coeficiente de correlación intraclase, la consistencia interna mediante el alfa de Cronbach, y la validez de criterio con respecto a la educación, el ingreso, la duración de la rehabilitación cardiaca y el sexo de los pacientes. Resultados: Después del análisis de coeficientes de correlación intraclase, un elemento ha sido eliminado. Las cuatro áreas se consideraron internamente consistentes $(a>0,7)$. Las diferencias significativas entre las puntuaciones totales medias y el ingreso $(p<0,01)$ apoyaron la validez del criterio. Doscientos sesenta y nueve $(89,6 \%$ ) pacientes tenían un alto nivel de kinesiofobia (puntuación > 37). Conclusiones: La versión en portugués de Brasil de la TSK-SV Cardiaca ha demostrado suficiente fiabilidad, consistencia y validez, apoyando su uso en futuros estudios.

Descriptores: enfermedad de la arteria coronaria; rehabilitación; encuestas y cuestionarios; miedo; movimiento; estudios de validación. 


\section{INTRODUCTION}

Coronary Artery Disease (CAD) is the leading cause of death worldwide in women and men ${ }^{1}$. Cardiac rehabilitation (CR) has a significant impact on morbidity and mortality among patients with documented $C A D$, improving functional capacity and decreasing re-hospitalization and overall medical costs ${ }^{2-4}$. Cardiac rehabilitation has been formally defined as "the enhancement and maintenance of cardiovascular health through individualized programs designed to optimize physical, psychological, social, vocational and emotional status" ${ }^{\prime \prime}$.

Cardiac rehabilitation is a complex intervention that may involve a variety of therapies, including the facilitation and delivery of secondary prevention through risk factor identification and modification in an effort to prevent disease progression and the recurrence of cardiac events $5^{5,6}$. Nonetheless, international clinical guidelines consistently identify exercise therapy as a central element of CR programs ${ }^{5-9}$. Previous meta-analysis ${ }^{2-4,10-12}$ showed that exercise-based CR programs reduce significantly the number of non-fatal Ml, cardiac death, and total mortality. Despite these benefits, CR programs are greatly underutilized, with rates of enrollment around $14 \%$ in middle-income countries ${ }^{13}$ such as Brazil.

According to Back et al. ${ }^{14}$, there is a need to identify obstacles that prevent patients from participants in CR and increasing their levels of physical activity. In this context, the Tampa Scale for Kinesiophobia $(T S K)^{15}$ - the only questionnaire that has been specifically designed to measure kinesiophobia - was validated to detect kinesiophobia in CAD patients (TSK-SV Heart) ${ }^{14}$. Kinesiophobia is "a condition in which a patient has an excessive, irrational and debilitating fear of physical movement and activity resulting from a feeling of vulnerability to painful injury or re-injury"16. Based on clinical experience, kinesiophobia can be a barrier to enroll and participate in CR programs once CAD patients often have doubts that physical activity can be performed safely after the diagnosis ${ }^{14}$. The TSK-SV has not been tested for the psychometric properties in the Brazilian population.

The objective of this study was to translate, culturally adapt and psychometrically validate the tsk-sv heart to portuguese.

\section{METHODS}

This study was reviewed and approved by the Ethics and Research Board of the State University of Santa Catarina (number 497.256), in accordance with CNS's resolution 196/96. The design of this study consisted of a series of cross-sectional, observational studies.

First, the translation and cultural adaptation was performed. This process followed strict norms approved by the author and co-authors and was based on the protocol proposed by Guillemin et al. ${ }^{17}$ : (1) initial translation, (2) back-translation, (3) committee review of those translations and back-translations, (4) pre-testing for equivalence using bilingual individuals, and (5) reexamination of the weighting of scores. The initial translation was performed by three independent translators, all aware of the objectives and concepts underlying the study and sought to detect ambiguities and unexpected meanings in the original items. The back-translation was performed by a forth translator, blinded to the initial objectives of the study and the original version. A committee of five bilingual experts reviewed all versions and a final version was generated. This version was then pre-tested in 30 patients. Results were used to refine the Portuguese version of the TSV-SV Heart.

Second, a psychometric validation was performed. The refined tool was administered to a larger sample of current CR participants from three programs in the Greater Florianopolis Area (Santa Catarina, south of Brazil), and one program in Natal (Rio Grande do Norte, north of Brazil). The instrument was applied through monitored self-administration. The researchers maintained a neutral stance during the administration, answering questions about the research and encouraging participants to answer all questions. The questionnaire was re-administered two weeks after the first application in 28 randomly selected participants to assess test-retest reliability. Data were collected between February and July of 2014.

For the psychometric validation, a convenience sample of 300 current $\mathrm{CR}$ patients was recruited from four institutions in 2 regions of Brazil (in the Northeast 1 private and in the South of Brazil 1 private and 2 public ones). These programs have a minimum duration of 3 months and no structured educational component. The inclusion criteria were the following: confirmed CAD diagnosis or multiple cardiovascular risk factors. The exclusion criteria were the following: younger than 18 years old, illiterate, any significant visual, cognitive or mental impairment which preclude the participant's ability to answer the questionnaire.

The Tampa Scale for Kinesiophobia (TSK) was designed to measure kinesiophobia in patients with persistent musculoskeletal pain ${ }^{15}$ and has been found to be reliable and valid for patients with CAD ${ }^{14}$. The TSK-SV Heart detects kinesiophobia in patients with CAD in four theoretical constructs or areas: danger, fear, avoidance, and dysfunction. The TSKSV comprises 17 statements rated on a 4-point Likert-type scale that ranged from 1 = "strongly disagree" to 4 = "strongly agree", and accordingly higher scores indicated greater degree of kinesiophobia. A cut-off $>37$ has been defined by Vlaeyen et al. ${ }^{18}$ and used for coronary artery patients by Back et al. ${ }^{14}$ as a high level of kinesiophobia.

Patients were characterized according to sex, age, educational level, family income, comorbidities, clinical risk factors, and duration of participation in CR. Participant clinical characteristics were obtained from the medical chart and socio-demographic characteristics were self-reported.

To test psychometric properties of the Portuguese TSK-SV Heart, it was investigated reliable measures as following: face and content validity, test-retest reliability, internal consistency, criterion validity, and a descriptive analysis.

\section{Statistical analysis}

The sample size calculation for the psychometric analysis was based on Hair and Anderson ${ }^{19}$ recommendation of a minimum sample size of 10 subjects per item, and/or at least 100 participants. Since the TSK-SV Heart has 17 items, a sample size of 300 is considered valid.

To test face and content validity a pre-test in patients with CAD was performed to provide feedback on the items and to check the time required to complete the questionnaire. Furthermore, patients gave their opinion on the face validity. Five experts were also asked to assess the face validity of the Portuguese TSK-SV Heart as part of the committee of experts' assessment.

To assess test-retest reliability, we used intraclass correlation coefficient (ICC). Bad items (ICC values lower than 0.70) ${ }^{20}$ were eliminated. Then, Cronbach's alpha was calculated for each subscale separately, in order to assess internal consistency. For this analysis, values higher than 0.70 were considered acceptable ${ }^{20}$, reflecting the internal correlation between items at the same area. The factor structure was an option of internal correlation assessment if the internal correlation between items in the areas was not confirmed.

Criterion validity was assessed by comparing TSK-SV Heart scores by gender ${ }^{21}$, level of education ${ }^{22}$, family income ${ }^{22}$, and duration in $\mathrm{CR}^{23}$. T-tests and Pearson's correlation were used as applicable. A descriptive analysis of the Portuguese version of the TSK-SV Heart was also performed. A mean total score was computed to reflect total kinesiophobia. Mean scores per area were also described. Differences in TSK-SV Heart scores based on socio-demographic and clinical characteristics were assessed. As subjects are rating importance, ceiling and floor effects are likely not applicable ${ }^{20}$. 
The SPSS - Statistical Package for Social Sciences - release $21.0^{24}$ was used for storing, sorting and analyzing data. The level of significance for all tests was set at 0.05 . When more than $20 \%$ of the items were not completed by the participant, their data were excluded from the analysis.

\section{RESULTS}

For the psychometric validation, 300 current CR patients (85\% of those approached to participate in this study) signed the consent form and completed the TSK-SV Heart in Portuguese. The socio-demographic and clinical characteristics of these participants are presented in Table 1 . The sample was primarily male $(n=207 ; 69 \%)$ and well-educated (University degree incomplete or higher, $n=179 ; 60 \%)$. The mean age was $62.1 \pm 10.1$ years old $(\min =37, \max =81$ ). To assess test-retest reliability, 28 of these patients were randomly selected and asked to complete the tool once more.

Table 1. Characteristics of the Participants for the Psychometric Validation of the Portuguese TSK-SV Heart $(n=300)$.

\begin{tabular}{|c|c|c|c|c|}
\hline \multicolumn{2}{|c|}{ Characteristic } & \multirow[t]{2}{*}{ n (\%) } & \multirow[t]{2}{*}{\begin{tabular}{|l|} 
Total score \\
(mean \pm SD) \\
\end{tabular}} & \multirow[t]{2}{*}{ p } \\
\hline Sociodemographic* & & & & \\
\hline \multirow{2}{*}{ Gender } & Male & $207(69 \%)$ & $43.81 \pm 4.77$ & 0.317 \\
\hline & Female & $93(31 \%)$ & $44.39 \pm 4.20$ & \\
\hline \multirow{8}{*}{ Educational Level } & \begin{tabular}{|l|} 
Never went to school \\
\end{tabular} & $5(1.6 \%)$ & $43.60 \pm 5.13$ & $<.001$ \\
\hline & \begin{tabular}{|l|} 
Primary school incomplete \\
\end{tabular} & $32(10.7 \%)$ & $43.68 \pm 3.43$ & \\
\hline & \begin{tabular}{|l|} 
Primary school complete \\
\end{tabular} & $29(9.6 \%)$ & $42.79 \pm 3.97$ & \\
\hline & $\begin{array}{c}\text { Secondary school } \\
\text { incomplete }\end{array}$ & $8(2.7 \%)$ & $44.50 \pm 3.51$ & \\
\hline & $\begin{array}{c}\text { Secondary School } \\
\text { complete }\end{array}$ & $46(15.4 \%)$ & $41.96 \pm 4.58$ & \\
\hline & $\begin{array}{c}\text { University degree } \\
\text { incomplete }\end{array}$ & $7(2.4 \%)$ & $37.00 \pm 4.00$ & \\
\hline & $\begin{array}{l}\text { University degree } \\
\text { complete }\end{array}$ & $93(31.0 \%)$ & $44.37 \pm 5.16$ & \\
\hline & Postgraduate & $79(2.7 \%)$ & $45.86 \pm 3.51$ & \\
\hline \multicolumn{5}{|l|}{ Monthly family } \\
\hline \multirow{5}{*}{ Income } & $\begin{array}{l}\text { Less than } 1 \\
\text { minimum salary }\end{array}$ & $17(5.6 \%)$ & $43.53 \pm 4.56$ & $<.001$ \\
\hline & 1-5 minimum salaries & $139(46.4 \%)$ & $44.24 \pm 4.04$ & \\
\hline & 5-10 minimum salaries & $114(38 \%)$ & $45.48 \pm 3.52$ & \\
\hline & 10-20 minimum salaries & $16(5.4 \%)$ & $38.06 \pm 3.53$ & \\
\hline & $\begin{array}{c}\text { Above } 20 \text { minimum } \\
\text { salaries }\end{array}$ & $13(4.3 \%)$ & $35.85 \pm 6.20$ & \\
\hline \multicolumn{5}{|l|}{ Clinicalt } \\
\hline \multirow{9}{*}{$\begin{array}{l}\text { Comorbidities } \\
\text { and risk factors }\end{array}$} & Hypertension & 247 (82.3\%) & $44.06 \pm 4.62$ & 0.589 \\
\hline & Dyslipidemia & $131(43.6 \%)$ & $43.07 \pm 4.90$ & $<.001$ \\
\hline & $\begin{array}{c}\text { Diabetes Mellitus } \\
\text { type I or II } \\
\end{array}$ & $103(34.3 \%)$ & $44.85 \pm 4.70$ & 0.018 \\
\hline & Obesity & 59 (19.6\%) & $44.00 \pm 4.91$ & 0.985 \\
\hline & \begin{tabular}{|c|} 
Smoking \\
\end{tabular} & $3(1 \%)$ & $42.67 \pm 2.08$ & 0.618 \\
\hline & Peripheral Vascular Disease & $33(11.0 \%)$ & $43.48 \pm 4.12$ & 0.392 \\
\hline & \begin{tabular}{|l|} 
Chronic Obstructive \\
Pulmonary Disease
\end{tabular} & $3(1.0 \%)$ & $46.24 \pm 2.49$ & 0.003 \\
\hline & Heart Failure & $29(9.7 \%)$ & $45.07 \pm 3.14$ & 0.185 \\
\hline & Stroke & $2(0.7 \%)$ & $44.29 \pm 4.24$ & 0.761 \\
\hline \multicolumn{5}{|l|}{ Acute event } \\
\hline & Acute Myocardial Infarction & $66(22.0 \%)$ & $43.53 \pm 4.21$ & 0.125 \\
\hline \multicolumn{5}{|c|}{\begin{tabular}{l|l|l} 
Revascularization & & \\
\end{tabular}} \\
\hline & Coronary Bypass & $92(30.6 \%)$ & $43.90 \pm 4.23$ & 0.826 \\
\hline \multicolumn{5}{|l|}{ Procedures } \\
\hline & Angioplasty & $190(63.3 \%)$ & $43.95 \pm 4.83$ & 0.833 \\
\hline \multicolumn{5}{|l|}{ Participation in CR } \\
\hline & 1-6 months & $91(30.4 \%)$ & $42.66 \pm 4.43$ & 0.013 \\
\hline & 6-12 months & $36(12.0 \%)$ & $45.14 \pm 3.66$ & \\
\hline & $12-24$ months & $44(14.6 \%)$ & $44.05 \pm 5.33$ & \\
\hline & More than 24 months & $126(42.0 \%)$ & $44.63 \pm 4.53$ & \\
\hline
\end{tabular}

SD: standard deviation. *Self-reported. † Extracted from medical chart.
During the process of translation and cultural adaptation, it was observed that 1 item (number 13) needed to be grammatically adapted in order to be used to the Brazilian context. This change was related to changing terms in order to improve clarity (not changing the context): the word "heart" was replaced by" problem". No other changes were required.

The 30 participants took a mean of $13.4 \pm 1.9$ minutes to complete the Portuguese TSK-SV Heart. In regards to content validity, after application and individual discussions between patients and researchers it was confirmed and the Portuguese TSK-SV Heart provides a clear description of the measurement aim, the target population, the concepts that are being measured, and the item selection.

As described elsewhere, the Portuguese version of the TSK-SV Heart was administered to $300 \mathrm{CR}$ participants to assess psychometric properties. Mean scores and completion rates are shown in Table 2.

The test-retest reliability was evaluated through the intraclass correlation coefficient (ICC) for each item and results are shown in Table 2. Item 14 ("t is really not safe for a person in my condition to be physically active/ exercise") did not meet the minimum recommended standard ${ }^{20}$ and, therefore, were excluded from the Portuguese version of the TSK-SV Heart.

Furthermore, the reliability of each area was assessed by Cronbach's alpha. All areas were considered internally consistent $(a>0.7)$. Table 2 also displays Cronbach's alpha of each area. The Cronbach's alpha of the instrument was 0.83 .

With regard to criterion validity, total TSK-SV Heart scores were compared by gender, level of education, family income, and duration in CR. In this context, patients with lower family income and months in CR had significantly greater kinesiophobia compared with their counterparts $(p<0.01)$. Surprisingly, patients with higher educational level presented significantly higher kinesiophobia than those with lower education $(p<.001)$.

\section{Descriptive analysis of the occurrence of kinesiophobia among CR patients}

The mean total score was 43.99 \pm 4.60 . Two hundred sixty nine (89.6\%) patients had a high level of kinesiophobia (TSK-SV Heart total scores $>37$ ) 14,23 $^{2}$ Regarding the 4 areas of the TSK-SV Heart, participants rated fear (2.76 \pm 2.37$)$ and dysfunction (2.76 \pm 1.73 ) as the higher theoretical frameworks related to kinesiophobia. Avoidance (2.38 \pm 1.53$)$ and danger $(2.48 \pm 1.14)$ were rated significantly lower $(p<0.5)$.

As shown on Table 1, mean TSK-SV Heart scores were related to educational level $(p<.001)$, monthly family income $(p<.001)$, duration in $C R(p=0.013)$, having dyslipidemia $(p<.001)$, being diabetic $(p=0.018)$, and having chronic obstructive pulmonary disease $(p=0.003)$.

\section{DISCUSSION}

This study sought to validate the TSK-SV Heart and adapt it for Portuguese-speaking patients with CAD. Although the occurrence of kinesiophobia in patients with CAD is not known, this condition has been shown to have a negative influence in the outcome of rehabilitation and is consequently of importance in the clinical setting ${ }^{23}$. The validation of the Portuguese version of the TSK-SV Heart followed strict norms, since the process of adapting an instrument to be used by a different population requires a greater effort than simply translation and idiomatic and semantic analysis ${ }^{17}$. Psychometric properties - content validity, test-retest reliability, internal consistency, and construct validity - were all established, and demonstrated the validity of this tool in Brazil.

Results of this study were consistent with those presented in the original validation ${ }^{14}$, particularly in relation to test-retest reliability (ICC $=0.83^{14}$ vs 0.84 ) and internal consistency (Chronbach's alpha $=0.78^{14}$ vs 0.83 ). In regards to content validity, patients with lower family 
Table 2. Means and Standard Deviations of TSK-SV Heart scores per item, item completion rates ( $n=300)$, ICC ( $n=28)$, and Cronbach's alpha per area.

\begin{tabular}{|c|c|c|c|c|c|c|}
\hline Area & Item & $\begin{array}{l}\text { Mean score } \neq \\
\text { Mean } \pm \text { SD }\end{array}$ & $\begin{array}{c}\text { Item completion } \\
\text { rates }(\%)\end{array}$ & ICC & $\begin{array}{c}\text { Cronbach's alpha } \\
\text { per area }\end{array}$ & $\begin{array}{l}\text { Mean score } \\
\text { per area }\end{array}$ \\
\hline \multirow[t]{4}{*}{ Danger } & 3. My body is telling me that I have something seriously wrong. & $3.04 \pm 0.82$ & $100 \%$ & 0.79 & 0.87 & $9.91 \pm 1.14$ \\
\hline & $\begin{array}{l}\text { 8. Just because something causes discomfort in my chest does not mean } \\
\text { that it is dangerous. }\end{array}$ & $1.90 \pm 0.73$ & $100 \%$ & 0.76 & & \\
\hline & $\begin{array}{l}\text { 11. I would not have my heart problems if there was not something } \\
\text { dangerous going on in my body. }\end{array}$ & $3.07 \pm 0.71$ & $100 \%$ & 0.88 & & \\
\hline & $\begin{array}{l}\text { 16. Even though something causes me a lot of heart problems, } \\
\text { I do not think that it is actually dangerous. }\end{array}$ & $1.91 \pm 0.66$ & $100 \%$ & 0.80 & & \\
\hline \multirow[t]{4}{*}{ Fear } & 1. I am afraid that I might injure myself during physical activity/exercising. & $2.58 \pm 0.96$ & $100 \%$ & 0.91 & 0.72 & $11.03 \pm 2.37$ \\
\hline & 7. In general, heart problem is always due to body injury. & $2.34 \pm 0.65$ & $100 \%$ & 0.91 & & \\
\hline & 9. I am afraid that I might injure myself accidentally. & $2.95 \pm 0.85$ & $100 \%$ & 0.76 & & \\
\hline & $\begin{array}{l}\text { 13. My heart problem tells me when I should stop being physically } \\
\text { active/exercising, so that I do not injure myself. }\end{array}$ & $3.16 \pm 0.71$ & $100 \%$ & 0.75 & & \\
\hline \multirow[t]{5}{*}{ Avoidance } & 2. If I tried to be physically active/exercise my heart problem would increase. & $2.40 \pm 0.99$ & $100 \%$ & 0.96 & 0.79 & $9.53 \pm 1.53$ \\
\hline & $\begin{array}{l}\text { 4. My heart problem would probably be relieved if I was physically } \\
\text { active/exercised. }\end{array}$ & $2.65 \pm 0.79$ & $100 \%$ & 0.83 & & \\
\hline & $\begin{array}{l}\text { 12. Even if I have a heart problem I would manage better if I was physically } \\
\text { active/exercised. }\end{array}$ & $2.64 \pm 0.96$ & $100 \%$ & 0.89 & & \\
\hline & $\begin{array}{l}\text { 14. It is really not safe for a person in my condition to be physically } \\
\text { active/exercise. }\end{array}$ & $2.47 \pm 0.91$ & $100 \%$ & $0.67+$ & & \\
\hline & $\begin{array}{l}\text { 17. No one should have to be physically active/exercise when he/she } \\
\text { has heart problems. }\end{array}$ & $1.84 \pm 0.72$ & $100 \%$ & 0.77 & & \\
\hline \multirow[t]{4}{*}{ Dysfunction } & 5. People are not taking my medical condition seriously enough. & $2.09 \pm 0.76$ & $100 \%$ & 0.90 & 0.77 & $11.05 \pm 1.73$ \\
\hline & 6. My heart problem has weakened me physically for the rest of my life. & $2.99 \pm 0.85$ & $100 \%$ & 0.86 & & \\
\hline & $\begin{array}{l}\text { 10. By being careful with unnecessary movements I can prevent my heart } \\
\text { problems from worsening. }\end{array}$ & $2.93 \pm 0.75$ & $100 \%$ & 0.72 & & \\
\hline & $\begin{array}{l}\text { 15. I cannot do the same things as others because there is a too big risk } \\
\text { that I will get heart problems. }\end{array}$ & $3.04 \pm 0.79$ & $100 \%$ & 0.90 & & \\
\hline Total & & $43.99 \pm 4.60$ & $100 \%$ & 0.84 & 0.83 & - \\
\hline
\end{tabular}

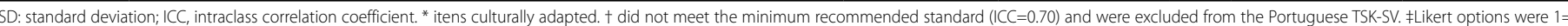
strongly disagree, $2=$ not important, $3=$ neutral, $4=$ =important, and $5=$ =ery important.

income had significantly greater kinesiophobia as described in the literature 22 . No differences were found regarding educational levels. Moreover, no differences between TSK-SV Heart scores and gender were observed. Although some studies assessing kinesiophobia and gender have reported that men have higher levels of kinesiophobia compared to women ${ }^{21,25,26}$, some of these results are considered equivocal and there are sparse data on cardiac patients to support this relationship. Finally, duration in $\mathrm{CR}$ (i.e. months participating in the program) showed inverse results compared to the literature ${ }^{23}$. In our study, patients that are participating in CR for more than 6 months had significantly greater kinesiophobia. One justification for this result is that participation and attendance are different things and patients can be register in the program but not attending and engaged. It is important to assess attendance in future studies.

Patient education is an important component of CR programs $s^{5,6}$ and is related to successful patient self-management of $C^{2} D^{27}$ and behavior change ${ }^{28}$. It has been shown to decrease adverse outcomes and even contribute to regression of the disease ${ }^{29}$. Items that comprise the Portuguese TSK-SV Heart should be included in the educational components of CR programs and discussed between patients and health providers. In addition, no studies have assessed the relationship between education and kinesiophobia, which is needed.

Caution is warranted when interpreting results. First, results are only generalizable to CR patients, which is a low proportion of CAD outpatients. Second, the test-retest was performed by 28 patients; however, a number of at least 50 is generally considered adequate. Third, there are some elements of the scale which require further assessment, such as construct validity related to behaviorally oriented constructs (as assessed in the original instrument ${ }^{14}$ ). Moreover, future research is needed to assess whether the scale is sensitive to change, such as a longitudinal study assessing kinesiophobia before and after CR participation. Finally, whether the Portuguese TSK-SV Heart is a valid tool to assess kinesiophobia in non-CR patients with CAD should be explored.

All authors declare no potential conflict of interest related to this article. 


\section{REFERENCES}

1. World Health Organization (WHO). Global status report on noncommunicable diseases 2010. Geneva: WHO; 2011

2. Clark AM, Hartling L, Vandermeer B, McAlister FA. Meta-analysis: secondary prevention programs for patients with coronary artery disease. Ann Intern Med. 2005;143(9):659-72.

3. Heran BS, Chen JM, Ebrahim S, Moxham T, Oldridge N, Rees K, et al. Exercise-based cardiac rehabilitation for coronary heart disease. Cochrane Database Syst Rev. 2011;(7):CD001800.

4. Lawler PR, Filion KB, Eisenberg MJ. Efficacy of exercise-based cardiac rehabilitation post-myocardial infarction: a systematic review and meta-analysis of randomized controlled trials. Am Heart J. 2011;162(4):571-84.

5. Stone JA, Arthur HM, Suskin N. Canadian guidelines for cardiac rehabilitation and cardiovascular disease prevention: translating knowledge into action. 3rd ed. Winnipeg MB: Canadian Association of Cardiac Rehabilitation; 2009

6. Buckley JP, Furze G, Doherty P, Speck L, Connolly S, Hinton S, et al. BACPR scientific statement: British standards and core components for cardiovascular disease prevention and rehabilitation. Heart. 2013;99(15):1069-71.

7. Fletcher GF, Balady GJ, Amsterdam EA, Chaitman B, Eckel R, Fleg J, et al. Exercise standards for testing and training: a statement for healthcare professionals from the American Heart Association. Circulation. 2001;104(14):1694-740

8. National Heart Foundation of Australia, Australian Cardiac Rehabilitation Association. Recommended framework for cardiac rehabilitation 2004. [Accesso em 2015 jul 15]. Disponível em: www. heartfoundation. org.au/SiteCollectionDocuments/Recommended-framework.pdf

9. Moraes RS, Nobrega ACL, Castro RRT, Negrão CE, Stein R, Serra SM, et al. Guidelines for Cardiac Rehabilitation. Arq Bras Cardiol. 2005;84(5):431-40.

10. Taylor RS, Brown A, Ebrahim S, Jolliffe J, Noorani H, Rees K, et al. Exercise-based rehabilitation for patients with coronary heart disease: systematic review and meta-analysis of randomized controlled trials. Am J Med. 2004;116(10):682-92

11. Jolliffe JA, Rees K, Taylor RS, Thompson D, Oldridge N, Ebrahim S. Exercise-based rehabilitation for coronary heart disease. Cochrane Database Syst Rev. 2001;(1):CD001800.

12. West R. Evaluation of cardiac rehabilitation programmes. In: Jones D, West R. Cardiac Rehabilitation. London, UK: BMJ Publishing; 1995. p.184-206.

13. Avram A, lurciuc S, Craciun L, Mancas S. Euroaspire III Romania: The need to reinforce cardiac rehabilitation patients with coronary artery disease. TMJ 2010;60(4):299-304.
14. Bäck M, Jansson B, Cider A, Herlitz J, Lundberg M. Validation of a questionnaire to detect kinesiophobia (fear of movement) in patients with coronary artery disease. J Rehabil Med. 2012;44(4):363-9.

15. Miller RP, Kori S, Todd D. The Tampa Scale: a measure of kinesiophobia. Clin J Pain. 1991;7(1):51-2.

16. Kori S, Miller R, Todd D. Kinisiophobia: a new view of chronic pain behavior. Pain Manag. 1990;3(1):35-43.

17. Guillemin F, Bombardier C, Beaton D. Cross-cultural adaptation of health-related quality of life measures: literature review and proposed guidelines. J Clin Epidemiol. 1993;46(12):1417-32.

18. Vlaeyen JW, Kole-Snijders AM, Boeren RG, van Eek H. Fear of movement/(re)injury in chronic low back pain and its relation to behavioral performance. Pain. 1995;62(3):363-72.

19. Hair JF, Anderson RE. Multivariate data analysis. New Jersey: Prentice Hall; 1998.

20. Terwee CB, Bot SD, de Boer MR, van der Windt DA, Knol DL, Dekker J, et al. Quality criteria were proposed for measurement properties of health status questionnaires. J Clin Epidemiol. 2007;60(1):34-42.

21. Bränström $H$, Fahlström M. Kinesiophobia in patients with chronic musculoskeletal pain: differences between men and women. J Rehabil Med. 2008;40(5):375-80

22. Picavet HS, Vlaeyen JW, Schouten JS. Pain catastrophizing and kinesiophobia: predictors of chronic low back pain. Am J Epidemiol. 2002;156(11):1028-34.

23. Bäck M, Cider Å, Herlitz J, Lundberg M, Jansson B. The impact on kinesiophobia (fear of movement) by clinical variables for patients with coronary artery disease. Int J Cardiol. 2013;167(2):391-7.

24. IBM Corporation. IBM SPSS Statistics for Windows, Version 21.0. Armonk, NY: IBM Corp; 2012.

25. Verbunt JA, Seelen HA, Vlaeyen JW, van der Heijden GJ, Knottnerus JA. Fear of injury and physical deconditioning in patients with chronic low back pain. Arch Phys Med Rehabil. 2003;84(8):1227-32.

26. Lundberg M, Larsson M, Ostlund H, Styf J. Kinesiophobia among patients with musculoskeletal pain in primary healthcare. J Rehabil Med. 2006;38(1):37-43.

27. Kärner A, Göransson A, Bergdahl B. Patients' conceptions of coronary heart disease--a phenomenographic analysis. Scand J Caring Sci. 2003;17(1):43-50.

28. Ghisi GL, Abdallah F, Grace SL, Thomas S, Oh P. A systematic review of patient education in cardiac patients: do they increase knowledge and promote health behavior change? Patient Educ Couns. 2014;95(2):160-74

29. Brown JP, Clark AM, Dalal H, Welch K, Taylor RS. Patient education in the management of coronary heart disease. Cochrane Database Syst Rev. 2011;(12):CD008895. 